\title{
INTEGRASI ILMU PENGETAHUAN MELALUI EPISTIMOLOGI KURIKULUM PENDIDIKAN ISLAM
}

\author{
Syadidul Kahar \\ Dosen STIT Babussalam Kutacane
}

\begin{abstract}
Abstrak: Perkembangan ilmu pengetahuan dan teknologi yang sangat cepat membawa dampak terhadap berbagai aspek kehidupan, termasuk terjadinya pergeseran fungsi institusi pendidikan. Seiring dengan tumbuhnya berbagai macam kebutuhan kehidupan, beban sekolah semakin berat dan kompleks. Lembaga pendidikan tidak saja dituntut untuk dapat membekali berbagai macam ilmu pengetahuan yang sangat cepat berkembang, akan tetapi juga dituntut untuk dapat mengembangkan minat dan bakat, membentuk moral dan kepribadian, bahkan dituntut agar anak didik dapat menguasai berbagai macam ketrampilan yang dibutuhkan untuk memenuhi dunia pekerjaan. Perubahan cepat ini memberikan arahan yang membuat pemisahan ilmu pengetahuan dengan islam. Salah satu prinsip kurikulum adalah relevansi yang dimaknai dengan kerelevansian (kesesuaian) kurikulum dengan perkembangan zaman. Kurikulum pendidikan Islam juga perlu menyesuaikan diri dengan perkembangan ilmu pengetahuan dan teknologi. Munculnya degradasi moral indonesia sekarang ini ditengarai karenakegagalan pendidikan Islam dalam mentransfer, menanamkan nilai, dan pentransferan ketrampilan nilai pendidikan Islam. Dari penelitian di lapangan ditemukan beberapa problematika kurikulum pendidikan Islam, antara lain; padatnya materi tetapi minim nilai, dominasi aspek kognitif, dankurang memperhatikan perkembangan peserta didik, serta dominasi pendekatan normatif dalam pengembangan isi kurikulum.Ilmu pengetahuan dewasa ini telah terkontaminasi oleh pemikiran-pemikiran dari dunia Barat yang sekuler dan bertentangan dengan nilai-nilai ajaran Islam. Oleh karena itu, perlu adanya suatu upaya melalui gerakan "Islamisasi ilmu pengetahuan" dengan mengambil segi-segi positif dari perkembangan-perkembangan modern seselektif mungkin, meskipun hal itu datangnya dari Barat yang diformulasikan dalam kurikulum pendidikan islam. Kurikulum pendidikan yang diterapkan yakni berusaha mengintegrasikan ilmu pengetahuan yang bersifat fard 'ain dan fard kifayah. Dan pada prinsipnya ini yang tertuang dalam konsep ta'dib sebagai suatu proses penanaman adab yang didalamnya telah mencakup 'ilm dan amal
\end{abstract}

Kata Kunci:Falsafah Pendidikan Islam, Kurikulum Pendidikan Islam

\section{Pendahuluan}

Pada dasarnya pendidikan islam memproyeksikan diri memproduk insan yang kamil, yaitu manusia yang sempurna dalam segala hal. Insan kamil yang dimaksud disini adalah keseimbangan manusia melalui keilmuan baik syariah dan ilmu sains 
yang dapat membawa manusia untuk syahadah manusia. Untuk meraih tujuan ini maka realisasinya harus sepenuhnya bersumber dari cita-cita yang diwahyukan Allah swt. dan Sunnah Nabi Muhammad saw. yang Tujuan pendidikan Islam tidak terlepas dari tujuan hidup manusia dalam Islam, yaitu untuk menciptakan pribadi-pribadi hamba Allah yang selalu bertakwa kepadaNya, dan dapat mencapai kehidupan yang berbahagia di dunia dan akhirat. Mengenai ini dalam Alquran telah dijelaskan dalam surah Al-Dzariat: 56:

Artinya: dan aku tidak menciptakan jin dan manusia melainkan supaya mereka mengabdi kepada-Ku.(Mengenalku) (Al-Dzariyat:56)

Berdasarkan ayat di atas sangat jelas bahwa tujuan dari pendidikan islam itu pada hakikatnya adalah realisasi dari cita-cita ajaran Islam itu sendiri, yang membawa misi bagi kesejahteraan umat manusia di dunia dan akhirat. Konsep ini senada dengan konsep yang ditawarkan Ibnu Khaldun bahwa tiga tingkat tujuan pendidikan Islam yaitu ${ }^{1}$ :

1. Pengembangan kemahiran dalam bidang tertentu,

2. Penguasaan keterampilan professional sesuai dengan tuntutan zaman,

3. Pembinaan pemikiran yang baik, oleh karena itupendidikan sebaiknya dibentuk dan direalisasikan dengan terlebihdahulu memperhatikan pertumbuhan dan perkembangan potensipsikologis peserta didik.

Hal ini dapat dipahami bahwa pendidikan islam pada dasarnya merupakan suatu proses perkembangan yang bertujuan. Tujuan proses perkembangan itu secara alamiah adalah kedewasaan atau kematangan. Sebab potensi yang dimiliki oleh manusia secara bertahap berjalan secara alamiah menuju kedewasaan dan kematangan. Potensi tersebut akan terwujud apabila dikondisikan secara alamiah dan sosial manusia memungkinkan. Ini merupakan suatu masalah dalam proses perkembangan manusia, karena setiap manusia memiliki potensi dan kehidupan sosial yang berbeda. Masalahnya terletak bagaimana suatu individu menghadapi proses

\footnotetext{
${ }^{1}$ Warul Walidin, Konstelasi Pemikiran Ibnu Khaldun, (Lhokseumawe: Nadiya Foundation, 2003), Hal. 105.
} 
perkembangan tersebut. Perkembangan tersebut tidak dapat terlepas dari konsep ilmu pengetahuan yang merupakan inti dari pendidikan itu sendiri.

Inti sebenarnya dari masalah yang timbul di negeri-negeri Muslim adalah masalah pengetahuan (the problem of knowledge). Tujuan Pendidikan bukan untuk menghasilkan warga negara yang lengkap (complete citizen), melainkan untuk menghasilkan manusia seutuhnya (complete man) sehingga dapat menjalankan fungsinya sebagai khalifah di permukaan bumi ini. Manusia benar-benar tahu dirinya dalam hal keajaiban komposisi tubuhnya, kehalusan strukturnya, dan sikap perbuatan dari kekuatan jiwa di dalamnya, dan perwujudan dari tindakan jiwa melalui hal itu, katakanlah sebuah karya yang kokoh dan ciptaan yang sempurna, maka dia siap untuk menilai (qiyas) semua makna (ma'ani) dari yang inderawi (sensible) melalui analogi dengannya, dan menyimpulkan darinya semua makna dari yang aqli (intelligible) dari dua dunia seluruhnya bersama-sama. Hubungan antara konsep Manusia sebagai representasi mikrokosmos ('alam saghir) dari alam semesta (al-'alam al-kabir), berbagai cabang pengetahuan dan organisasi, instruksi, penanaman, dan penyebaran pengetahuan di universitas telah dikemukakan secara meyakinkan oleh al-Attas ${ }^{2}$.

Dalam peradapan islam, penggunaan ilmu harus sesuai dengan standar syariah islam. Abu Ishaq As Syatibi dalam Al Rasyidin menjelaskan bahwa ${ }^{3}$, tujuan dari penetapan standar itu adalah:

1. Memelihara agama

2. Memelihara akal

3. Memelihara keturunanan

4. Memelihara harta

Hakikat dari ilmu pengetahuan itu adalah menghantarkan yang berilmu kepada sipemilik ilmu yaitu Allah swt. Pada zaman sekarang ini, Ilmu bukan lagi merupakan sarana yang membantu manusia mencapai tujuan hidupnya, namun bahkan mengubah hakikat kemanusiaan itu sendiri, dengan perkataan lain ilmu bukan

\footnotetext{
${ }^{2}$ Wan Mohd Nor Wan Daud, Educational Philosophy and Practice of Syed Muhammad Naquib al-Attas: An Exposition on the Original Concept of Islamization (Kuala Lumpur: ISTAC, 1998); hal. 2

${ }^{3}$ Al Rasyidin, Falsafah Pendidikan Islam:membangun Kerangka Ontologi, Epistimologi, dan Aksiologi Praktik Pendidikan Islam, (Bandung: Cipta Pustaka Media Perintis, 2008), hal.147
} 
lagi merupakan sarana yang membantu manusia mencapai tujuan hidupnya menjadi insan yang kamil, namun juga menciptakan tujuan hidup itu sendiri. Maksudnya adalah manusia sudah membuat tujuan sendiri sesuai dengan nafsunya atau kemauannya sendiri dan untuk kepentingannya sendiri.

Kegunaan pendidikan secara moral harus ditujukan untuk kebaikan manusia tanpa merendahkan martabat atau mengubah hakikat kemanusiaan. Pendidikan itu implementasinya selalu terkait dengan aksiologinya. Dalam hal ini akan dijelaskan seberapa jauh pendidikan islam itu mempunyai peranan dalam membatu mencapai kehidupan manusia yang sejahtera di dunia ini dan di akhirat. Manusia belajar dari pengalamannya dan berasumsi bahwa alam mengikuti hukum-hukum dan aturanaturannya, dalam hal ini berarti wahyu Allah swt dan hadis. Pendidikan islam merupakan hasil kebudayaan manusia, dimana lebih mengutamakan kuantitas yang obyektif dan mengesampingkan kualitas subjektif yang berhubungan dengan keinginan pribadi sehingga dengan pendidikan, manusia tidak akan mementingkan dirinya sendiri.

Realita alam semesta ini dan eksistensi manusia yang memiliki jasmani dan rohani, anak-anak sebagai peserta didik harus dibimbing, dibina dan ditumbuh kembangkan untuk memahami realitas dunia yang nyata ini dan untuk membimbing pengertian anak-anak dalam memahami suatu realita bukanlah semata-mata kewajiban sekolah atau pendidikan. Kewajiban sekolah juga untuk membina kesabaran tentang kebenaran yang berpangkal atas realita. Ini berarti realita itu sebagai tahap pertama, sebagai stimulus untuk menyelami kebenaran. Peserta didik juga secara sistematis wajib dibina potensi berpikir kritis untuk mengerti kebenaran sesuai dengan tingkatan kemampuannya dalam memahami realita tersebut.Dengan pembinaan dan bimbingan tersebut, diharapkan peserta didik mampu mengerti perubahan-perubahan di dalam lingkungan hidupnya baik tentang adat istiadat, tata sosial dan pola-pola masyarakat, maupun tentang nilai-nilai moral dan hukum. Daya pikir yang kritis akan sangat membantu pengertian tersebut. Kewajiban pendidik kaitannya dengan ontologis ini ialah membina daya pikir yang tinggi dan kritis pada anak. Implikasi pandangan ontologi dalam filsafat pendidikan islam terhadap 
pendidikan islam adalah bahwa dunia pengalaman manusia yang harus memperkaya kepribadian bukanlah hanya alam raya dan isinya dalam arti sebagai pengalaman sehari-hari.

Berdasarkan uraian di atas dapat dipahami bahwa dalam pandangan filsafat pendidikan islam kurikulum pendidikan islam itu adalah alam semesta ini. Dengan memformulasikan alam ini dalam bentuk uraian ilmu pengetahuan maka tujuan ahirnya adalah siswa sebagai peserta didik dapat menjaga kelangsungan kenyamanan alam semesta ini. Konsep formulasi kurikulum in akan mengarahkan integrasi pengetahuan. Inilah yang akan menjadi pembahasan dalam artikel ini, dengan kurikulum ini diharapkan akan membawa peserta didik memandang ilmu pengetahuan dalam kacamata islam. Perkembangan ilmu pengetahuan dan teknologi yang sangat cepatmembawa dampak terhadap berbagai aspek kehidupan, termasuk terjadinyapergeseran fungsi institusi pendidikan. Seiring dengantumbuhnya berbagai macam kebutuhan kehidupan, beban sekolah semakinberat dan kompleks. Lembaga pendidikan tidak saja dituntut untuk dapat membekaliberbagai macam ilmu pengetahuan yang sangat cepat berkembang, akantetapi juga dituntut untuk dapat mengembangkan minat dan bakat,membentuk moral dan kepribadian, bahkan dituntut agar anak didik dapatmenguasai berbagai macam ketrampilan yang dibutuhkan untuk memenuhidunia pekerjaan ${ }^{4}$. Perubahan cepat ini memberikan arahan yang membuat pemisahan ilmu pengetahuan dengan islam. Salah satu prinsip kurikulum adalah relevansi, yang dimaknai dengankerelevansian (kesesuaian) kurikulum dengan perkembangan zaman.Kurikulum pendidikan Islam juga perlu menyesuaikan diri denganperkembangan ilmu pengetahuan dan teknologi.

\footnotetext{
${ }^{4}$ Wina Sanjaya, Kurikulum dan Pembelajaran: Teori dan Praktik Pengembangan KTSP, (Jakarta; Kencana Prenada Media Group, 2008), hlm. 5
} 


\section{Pembahasan}

\section{a. Problematika Pendidikan Islam dalam Tinjauan Filsafat Pendidikan Islam}

Manusia jika dikelompokkan dari segi kajian ontologi maka dapat dilihat dari tiga sudut pandang, yaitu manusia sebagai individu, manusia sebagai makhluk sosial dan manusia yang hidup dialam. Jika ditinjau dari manusia hidup di alam, berarti perkembangan dari kehidupan manusia itu tergantung bagaimana cara manusia menghargai alam dan mengajarkan kepada generasi selanjutnya. Pada dasarnya alam ini diciptakan Allah swt untuk manusia. Walaupun demikian bukan berarti manusia bertindak semena-mena berbuat sekendak hatinnya. Kemampuan manusia untuk menguasai alam ini terbatas sesuai dengan yang telah ditaqdirkan Allah swt. Tugas manusia sebagai khalifah dipermukaan bumi ini adalah untuk menjaga keseimbangan alam dan menjalankan perintah allah swt.

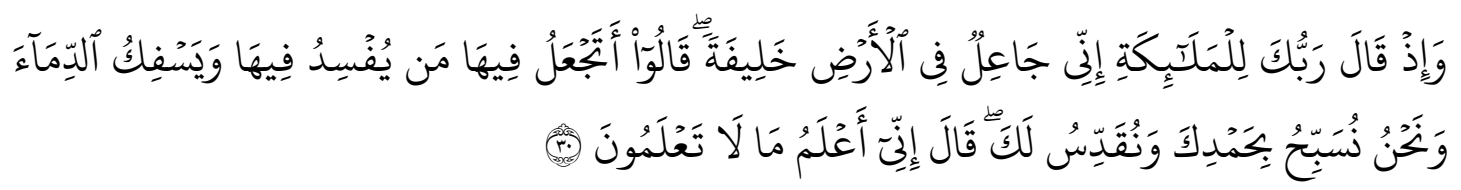

Artinya: ingatlah ketika Tuhanmu berfirman kepada Para Malaikat: "Sesungguhnya aku hendak menjadikan seorang khalifah di muka bumi." mereka berkata: "Mengapa Engkau hendak menjadikan (khalifah) di bumi itu orang yang akan membuat kerusakan padanya dan menumpahkan darah, Padahal Kami Senantiasa bertasbih dengan memuji Engkau dan mensucikan Engkau?" Tuhan berfirman: "Sesungguhnya aku mengetahui apa yang tidak kamu ketahui." (QS. Al Baqarah: 30)

Walau demikian, meskipun telah ditundukkan untuk manusia dan dirancang sesuai dengan hukum-hukum Allah swt sehingga memungkinkan untk diketahui manusia, namun Allah swt tetap memerintahkan manusia untuk mempelajari alam semesta dengan semua fonomena dan noumenanya ${ }^{5}$. Alam ini merupakan objek ilmu pengetahuan yang dapat diolah untuk pemanfaatan bagi manusia.

\footnotetext{
${ }^{5}$ Al Rasyidin, Falsafah Pendidikan..., hal.11.
} 
Manusia sebagai mahluk individu, yang pada dasarnya manusia itu sendiri berkembang dan bergerak menuju kearah kesempurnaan. Proses perubahan dan perkembangan ini baik fisik maupun rohani manusia perlu diberikan pendidikan agar dapat menjalani kehidupan ini. Dikarenakan manusia itu sendiri merupakan integrasi yang utuh antara dimensi material dan non material, maka pendidikan islami harus merupakan suatu proses memberikan bantuan kemudahan kepada peserta didik untuk dapat mengembangkan kedua dimensi tersebut dengan segenap daya-daya potensi yang dimilikinya ${ }^{6}$.

Manusia sebagai mahluk sosial, merupakan kehidupan manusia itu sendiri yang hidup dimasyarakat. Masyarakat itu sendiri merupakan suatu kesatuan individu yang memiliki keinginan yang sama dan tujuan yang sama. Mencermati hal tersebut, maka setiap masyarakat memiliki tanggung jawab edukatif untuk mengingatkan, mengajak, mendidik, melatih, mengarahkan dan membimbing sesamanya agar tetap berpegang teguh pada perjanjian atau syahadah primordialnya dengan Allah swt ${ }^{7}$. Dalam hal ini, harapan utama dalam filsafat pendidikan islam adalah agar terbentuknya peradapan manusia.Ketiga kajian tersebut di atas merupakan hakikat dari alam, manusia, dan sosial. Ketiga hal tersebut merupakan objek dari pendidikan itu sendiri yang ide-idenya dari filsafat pendidikan. Dengan hal ini akan menjadikan objek kajian kurikulum sehingga akan memberikan manfaat untuk menjaga keseimbangan alam hal inilah yang memberikan konsep yang jelas bagi manusia untuk menjalankan fungsinya sebagai khalifah di bumi.

Dalam lingkungan yang nampak ini termasuk segala yang mengalami perubahan. Disini terdapat ketidaksempurnaan, ketidakteraturan, ketidaktenangan, dan inilah alam kesulitan dan kesusahan, alam penderitaan dan kesengsaraan dan alam kejahatan atau dosa. Sebaliknya keadaan alam realitas yang sejati tidaklah demikian, dia merupakan alam ideal, alam pikiran sejati dan murni. Jadi di alam inilah terdapat nilai-nilai yang langgeng, kualitas yang abadi dan disanalah terdapat keteraturan, kebenaran sejati, kemakmuran, kedamaian, dan kelestarian segala

\footnotetext{
${ }^{6} \mathrm{Ibid}, \ldots . .$, hal.30.

${ }^{7}$ Ibid,..., hal.38.
} 
sesuatu. Hakikat dari alam, manusia, dan sosial masyarakat merupakan kajian ontologi filsafat pendidikan islam. Ini berarti pendidikan islam itu sendiri harus seirama dengan hal tersebut agar hakikat dari tujuan pendidikan itu tercapai yaitu menjadi insan yang kamil yang mendapat kesejahtraan dunia dan akhirat.

Untuk tercapainya tujuan pendidikan tersebut perlu adanya bimbingan dan pembinaan terhadap peserta didik. Dengan pembinaan dan bimbingan tersebut, diharapkan peserta didik mampu mengerti perubahan-perubahan di dalam lingkungan hidupnya baik tentang adat istiadat, tata sosial dan pola-pola masyarakat, maupun tentang nilai-nilai moral dan hukum. Daya pikir yang kritis akan sangat membantu pengertian tersebut. Kewajiban pendidik kaitannya dengan ontologis ini ialah membina daya pikir yang tinggi dan kritis pada anak. Implikasi pandangan ontologi dalam filsafat pendidikan islam terhadap pendidikan islam adalah bahwa dunia pengalaman manusia yang harus memperkaya kepribadian bukanlah hanya alam raya dan isinya dalam arti sebagai pengalaman sehari-hari.

Berdasarkan uraian diatas bahwa manusia tidak bisa terlepas dari alam, perkembangan individu manusia itu sendiri, dan kehidupan social manusia itu sendiri. Dari tiga konsep telaah inilah kajian ontology menguraikan bagaimana konsep pendidikan itu sendiri berdasarkan filsafat pendidikan islam yang meliputi tentang bagaiman hakikat pendidik, peserta didik, kurikulum, serta sarana dan prasarana pendidikan. Dalam filsafat pendidikan islam pendidik itu adalah Allah swt itu sendiri. Jadi, pendidik disini bukanlah yang tergambar seolah-olah berdiri didepan kelas. Kajian ontologi disini adalah sebagai pendidik maka harus dapat meresapi bagaimana sifat-sifat allah swt. Allah itu maha Rahim, maka sebagai pendidik harus dapat mengimplementasikan sifat kasih sayang itu terhadap dirinya untuk mendidik anak didiknya. Begitu juga dengan sifat-sifat Allah swt. lainnya.

Jadi dapat di dikatakan bahwa pendidik dalam filsafat pendidikan islam dalam kajian ontologi filsafat pendidikan islam adalah Siapa saja orang yang bertanggung jawab terhadap perkembangannya anak didik yang mengimplementasikan sifat-sifat Allah swt. Orang yang paling bertanggung jawab adalah orang tua (ayah, ibu) anak didik, karena dapat dilihat dari dua hal, yaitu Pendidik berarti juga orang dewasa yang 
bertanggung jawab memberi pertolongan pada anak didik dalam perkembangan jasmani dan rohaninya, agar menacapai tingkat kedewasaan, mampu berdiri sendiri dan mematuhi tingkat kedewasaannya, mampu berdiri sendiri memenuhi tugasnya sebagai hamba dan khalifah Allah SWT. Dan mampu sebagai makhluk sosial, dan sebagai makhluk individu yang mandiri. Pendidik harus mampu membentuk rupa mental-rohaniah anak didik. Sebab pada hakiktnya pendidik telah merepkan kedalam jiwamu dengan ragam pengetahuan dan membimbingnya ke jalan keselamatan dan keabadian, seperti apa yang telah dilakukan oleh Allah swt ketika mengajarkan Nabi Adam as.Begitu juga halnya dengan peserta didik dan kurikulum, dalam kajian ontologi filsafat pendidikan islam sistem pendidikan tersebut dikembalikan kepada Allah swt. Yang berupa wahyu ilahi dan sunnah rasulullah saw. konsep tersebut sudah tergambar jelas dalam islam bagaimana mekanismenya dan konsepnya.

Sedemikian jauh dunia pendidikan islam dianggap sebagai proses penyerahan kebudayaan islam umumnya, dan ilmu pengetahuan khususnya. Yang menjadi pertanyaan adalah apa sesungguhnya ilmu itu, dari mana sumber ilmu tersebut dan bagaimana proses terjadinya. Inilah urusan epistimologi filsafat pendidikan islam itu. Suryasumantri dalam Rasydin mengatakan bahwa epistimologi adalah bagian dari filsafat ilmu membahas tentang proses dan prosedur menggali ilmu, metode untuk meraih ilmu yang benar, makna dan kriteria kebenaran serta sarana yang digunakan untuk mendapatkan ilmu ${ }^{8}$.Dalam alquran disebutkan bahwa manusia memiliki potensi yang dapat digunakan untuk meraih ilmu sehingga dapat menjalan tugasnya sebagai khalifah dipermukaan bumi ini.

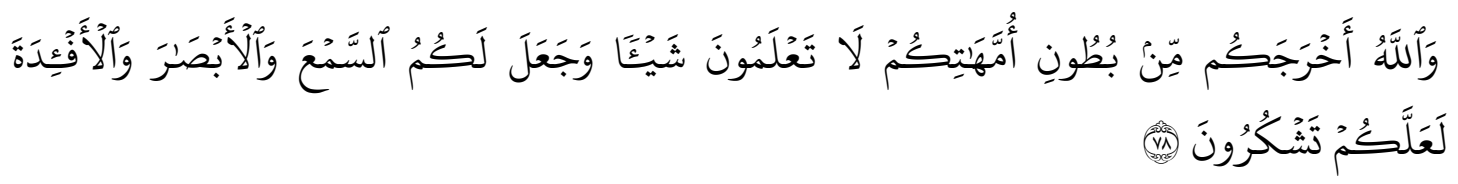

Artinya:Dan Allah mengeluarkan kamu dari perut ibumu dalam Keadaan tidak mengetahui sesuatupun, dan Dia memberi kamu pendengaran, penglihatan dan hati, agar kamu bersyukur. (QS. An Nahl:78)

\footnotetext{
${ }^{8}$ Al Rasyidin dan Ja'far, Filsafat Ilmu Dalam Tradisi Islam, (Medan: Perdana Publishing, 2015), hal. 79.
} 
Berdasarkan ayat tersebut, potensi-potensi yang dimiliki oleh manusia adalah jiwa, pendengaran, penglihatandan hati. Potensi-potensi inilah yang digunakan untuk memproleh ilmu. Diahir ayat dinyatakan bahwa dengan potensi-potensi yang telah diamanahkan Allah swt kepada manusia supaya manusia itu bersyukur. Makasud bersyukur disini adalah bertanggung jawab dan menggunakan amanah yang telah diberikan Allah swt dengan baik. Mula-mula manusia percaya bahwa dengan kekuasaan pengenalannya ia dapat mencapai realitas sebagaimana adanya. Epistomologi mengkaji mengenai apa sesungguhnya ilmu, dari mana sumber ilmu, serta bagaimana proses terjadinya. Dengan menyederhanakan batasan tersebut, Brameld mendefinisikan epistomologi memberikan kepercayaan dan jaminan bagi guru bahwa ia memberikan kebenaran kepada murid-muridnya ${ }^{9}$. Kebenaran dalam filsafat pendidikan islam adalah kebenaran yang bersumber dari Al Quran dan hadis. Tetapi tidak menafikan sumber lain yang berdasarkan pemikiran manusia selama pemikiran itu sejalan dengan sumber islam itu sendiri.

Secara praktis, fungsi utama agama adalah sebagai sumber nilai (ahklak) untuk dijadikan pegangan dalam hidup budaya manusia. Agama juga memberikan orientasi atau arah dari tindakan manusia. Orientasi itu memberikan makna dan menjauhkan manusia dari kehidupan yang sia-sia. Nilai, orientasi, dan makna itu terutama bersumber dari kepercayaan akan adanya Tuhan dan kehidupan setelah mati atau yang disebut dengan alam akhirat. Dalam filsafat pendidikan islam, kegunaan epistimologi adalah untuk memproleh ilmu pengtahuan sehingga kegunaan ilmu tersebut dapat digunakan untuk menjelaskan, meramal atau memerkirakan, dan mengontrol. Penjelasan tersebut bersumber dari alquran dan hadis. Dihadapkan pada masalah praktis, teori akan memerkirakan apa yang akan terjadi dalam pendidikan. Dari perkiraan itu, kita memersiapkan langkah-langkah yang perlu dilakukan untuk mengontrol segala hal yang mungkin timbul, entah itu merugikan atau menguntungkan.

\footnotetext{
${ }^{9}$ Muhammad Noor Syam, Filsafat Kependidikan dan Dasar Filsafat Kependidikan Pancasila, (Surabaya: Usaha Nasional, 1986), hal. 32
} 
Dalam kajian epistimologi filasafat pendidikan islam, ilmu itu dengan jenis apapun berasal dari Allah swt. Ketika ditinjau dari berbagai aspek maka muncullah dikotomi ilmu pengetahuan itu sendiri. Dikotomi ilmu adalah sikap yang membagi atau membedakan ilmu secara teliti dan jelas menjadi dua bentuk atau dua jenis yang dianggap saling bertentangan serta sulit untuk diintegralkan Dengan demikian, apapun bentuk pembedaan secara diametral terhadap ilmu secara bertentangan adalah berarti dikotomi ilmu. Sehingga secara umum timbul istilah "ilmu umum (non agama) dan ilmu agama; ilmu dunia dan ilmu akhirat; ilmu hitam dan ilmu putih; ilmu eksak dan ilmu non-eksak, dan lain-lain. Bahkan ada pembagian yang sangat ekstrim dalam pembagian ilmu pengetahuan dengan istilah seperti ilmu akhirat dan ilmu dunia; ilmu syar'iyyah dan ilmu ghairu syar'iyyah ${ }^{10}$.

Kegunaan pendidikan secara moral harus ditujukan untuk kebaikan manusia tanpa merendahkan martabat atau mengubah hakikat kemanusiaan. Pendidikan itu implementasinya selalu terkait dengan aksiologinya. Dalam hal ini akan dijelaskan seberapa jauh pendidikan islam itu mempunyai peranan dalam membatu mencapai kehidupan manusia yang sejahtera di dunia ini dan di akhirat. Manusia belajar dari pengalamannya dan berasumsi bahwa alam mengikuti hukum-hukum dan aturanaturannya, dalam hal ini berarti wahyu Allah swt dan hadis. Pendidikan islam merupakan hasil kebudayaan manusia, dimana lebih mengutamakan kuantitas yang obyektif dan mengesampingkan kualitas subjektif yang berhubungan dengan keinginan pribadi sehingga dengan pendidikan, manusia tidak akan mementingkan dirinya sendiri.

Pembentukan kepribadian seseorang sangat dipengaruhi oleh dimensi ruh yang merupakan anugerah Allah swt, bukan dimensi jasad. Dalam persepektif ini, jasad pada hakikatnya adalah wahana berlakunyad dorongan atau keinginankeinginan ruhiyah manusia ${ }^{11}$. Dalam persepektif islam, agar tercapainya insan yang kamil melalui pendidikan maka perlu keseimbangan aqal, qalbu, dan nafs. Berdasarkan hal ini, proses ta'lim, tarbiyah, atau ta'dib dalam pembentukan

\footnotetext{
${ }^{10}$ Baharuddin, Dkk., Dikotomi Pendidikan Islam: Historisitas dan Implikasi Pada Masyarakat Islam, (Bandung: Remaja Rosdakarya, 2011), hal. 44

${ }^{11}$ Al Rasyidin, Falsafah Pendidikan,... hal 88
} 
kepribadian muslim harus diawali dari tazkiyatun nafs. Ketika nafs sudah bersih dari pengaruh-pengaruh yang tidak baik maka dengan mudahnya menerima inti dari agama itu sendiri.

Tujuan individual dalam pendidikan Islam sangat dicerminkan oleh sikap atau perilaku masing-masing individu. Sebagaimana yang dijelaskan oleh Omar Mohammad At-Toumy Al-Syaibani, bahwa tujuan-tujuan individual adalah yang berkaitan dengan individu-individu, pelajaran (learning) dan dengan pribadi-pribadi mereka, dan apa yang berkaitan dengan individu-individu tersebut ada perubahan yang diinginkan pada tingkah laku, aktivitas dan pencapaiannya, dan pada pertumbuhan yang diingini pada pribadi mereka, dan pada persiapan yang dimestikan kepada mereka pada kehidupan dunia akhirat ${ }^{12}$.

Konsep tujuan tertinggi atau terakhir dalam pendidikan Islam ada akhirnya sesuai dengan tujuan hidup manusia dan peranannya sebagai ciptaan Allah SWT. yaitu menjadi hamba Allah yang paling taqwa, mengantarkan subjek didik sebagai khalifatullah fil ard (wakil Allah di bumi), memperoleh kesejahteraan, kebahagiaan hidup di dunia sampai akhirat. Tujuan tertinggi pendidikan Islam dapat terlihat bahwa pendidikan Islam itu lebih banyak ditujukan kepada perbaikan sikap mental yang terwujud $^{13}$. Artinya konsep tujuan pendidikan Islam tertinggi tidak hanya berorientasi pada teoritis saja, akan tetapi berjalan seimbang antara Teoritis dan praktis. Sehingga pada intinya tujuan pendidikan Islam tidak memisahkan iman dan amal shaleh. Tujuan pendidikan yang ingin dicapai dengan pembacaan, penyucian, dan pengajaran sebagaimana disebutkan dalam ayat tersebut sama dengan pengabdian kepada Allah. Sehingga dapat dikatakan tujuan tertinggi pendidikan Islam meliputi aspek kejiwaan yang abstrak yaitu filsafat hidup dan kepercayaan. Dengan kata lain pendidikan Islam secara filosofis berorientasi kepada nilai-nilai Islam bersasaran pada tiga dimensi hubungan manusia selaku khalifah di muka bumi, yakni sebagai berikut;

1. Menanamkan sikap hubungan yang seimbang dan selaras dengan Tuhannya,

12 Omar Mohammad At-Toumy Al-Syaibani, Falsafah pendidikan Islam, (Jakarta: Bulan Bintang, 1979), hlm. 399

${ }^{13}$ Nur Uhbiyati, Ilmu Pendidikan Islam, (Bandung; CV. Pustaka Setia, 1997), hlm. 12 
2. Membentuk sikap hubungan yang harmonis, selaras dan seimbang dengan masyarakatnya. Mengembangkan kemampuan untuk menggali, mengelola, dan memanfaatkan kekayaan alam bagi kepentingan kesejahteraan hidupnya dan hidup sesamanya serta bagi kepentingan ubudiyahnya kepada Allah SWT. Dengan dilandasi sikap yang harmonis pula ${ }^{14}$.

\section{b. Islamimasi Pendidikan}

Krisis ilmu pengetahuan disebabkan oleh pemisahan perkembangan dari interaksi wujud universal. Di satu sisi ilmu pengetahuan memperdalam pengetahuan tentang materi untuk memanfaatkannya. Berlawanan dengan pendekatan Ihwan assafa menganalisa materi berdasarkan nilai-nilai etis dan dimensi spiritual. Universalisme dan dasar etisnya, termasuk hati nurani yang lembut, mengorientasikan pengetahuan ke arah humanistik, sehingga mencegah ilmu-ilmu keluar dari tujuan manusianya ${ }^{15}$. Universalisme mendasarkan pada kesatuan manusia, kesatuan manusia didasarkan pada interaksi akal dan roh, jiwa dan tubuh, kesatuan hidup pada integritas makrokosmos dan mikrokosmos. Sebagai alternatif perpecahan antara humaniora dan ilmu alam digunakan pendekatan transdisipliner mereka kesempatan untuk mengintegrasikan kembali sains dan alam. Hal inilah sebagai jalan keluar dari krisis ilmu pengetahuan dalam memperoleh kembali kesatuan universal manusia, masyarakat, alam dan kosmos.

Pada awal era modern para pemikir modern dan pemimpin muslim mulai menyadari betapa pentingnya pendidikan sebagai upaya memajukan umat, terutama untuk menghadapi hegemoni sosial, ekonomi dan kebudayaan Barat. Dalam masyarakat yang dinamis, pendidikan memegang peranan yang menentukan eksistensi dan perkembangan masyarakat, ekonomi dan budaya tersebut. Oleh sebab itu, pendidikan merupakan usaha melestrarikan dan mengalihkan serta mentranspormasikan nilai-nilai kebudayaan dalam segala aspek dan jenisnya kepada

\footnotetext{
${ }^{14}$ Muzayyin Arifin, Filsafat Pendidikan Islam, (Jakarta; PT Bumi Aksara, 2005), hlm.121

${ }^{15}$ Anna-Teresa Tymieniecka (ed), Reason, Spirit and the Sacral in the New Enlightenment Islamic Metaphysics Revived and Recent Phenomenology of Life,(Hampshire, USA : 2011.VOLUME 5), hal.51
} 
generasi penerus. Pendidikan sebagai cara paling efektif untuk menghadapi persoalaan kejumudan dan kemunduran umat selama ini. Pendidikan Islam diharapkan bisa mengakomodasikan perkembangan-perkembangan baru di Barat.

Meskipun demikian Pendidikan Islam sebagai ilmu, sampai saat ini masih kurang mendapatkan perhatian yang serius di kalangan pemikir-pemikir muda, khususnya dalam kajian filosofinya. Padahal kajian filosofi suatu ilmu merupakan kajian inti yang menjadi landasan pengembangan ilmu tersebut. Karena itu sangat urgen sekarang untuk kembali menelusuri kajian-kajian Ilmu Pendidikan Islam dari sudut pandang filosufinya.Epistemologi adalah teori pengetahuan, yaitu membahas tentang bagaimana cara mendapatkan pengetahuan dari obyek yang ingin dipikirkan $^{16}$. Hamlyn Mendefinisikan epistemologi sebagai cabang filsafat yang berurusan dengan hakikat dan lingkup pengetahuan dan pengandai-pengandaiannya serta secara umum hal itu dapat diandalkannya sebagai penegasan bahwa orang memiliki pengetahuan ${ }^{17}$. Selanjutnya Tafsir, menjelaskan bahwa epistemologi sain adalah ilmu yang membahas tentang objek pengetahuan sain, cara memperoleh pengetahuan dan cara mengukur benar tidaknya pengetahuan itu ${ }^{18}$.

Objek pengetahuan sain ialah objek-objek empiris yang ada dalam ruang lingkup pengalaman manusia. Dengan demikian Ilmu Pendidikan Islam semestinya dibangun (construct) berdasarkan pengalaman yang terkait usaha manusia dalam membentuk kepribadian, akhlak, mengembangkan fitrah dan semua potensi manusia secara maksimal. Arifin, menegaskan bahwa ruang lingkup atau objek pendidikan Islam itu mencakup kegiatan-kegiatan pendidikan yang dilakukan secara konsisiten dan berkesinambungan dalam bidang atau lapangan hidup manusia yang meliputi ${ }^{19}$; (1). Lapangan hidup keagamaan, agar perkembangan pribagi manusia sesuai dengan

\footnotetext{
${ }^{16}$ MujamilQomar, EpistemologiPendidikan Islam DariMetodeRasionalHinggaMetodeKritik, (Jakarta: Erlangga, 2005),h. 43

${ }^{17}$ MachfudzIbawi, Modus Dialog di PerguruanTinggi Islam, dalamAminHusniet.al., Citra Kampus Religius Urgensi Dialog Konsep Teoritik Empirik Dengan Konsep Normatif Agama, (Surabaya: PT. Bina Ilmu, 1986), h. 100

${ }^{18}$ Ahmad Tafsir, Filsafat Ilmu: Mengurai Ontologi, Epistimologi dan Aksiologi Pengetahuan, (Bandung: Rosda Karya, 2009), h. 27

${ }^{19}$ Muzayin Arifin, Ilmu Pendidikan Islam; Suatu Tinjauan Teoritis dan Praktis Berdasarkan Pendekatan Interdisipliner, (Jakarta; Bumi Aksara, 1991), h. 17
} 
norma-norma ajaran Islam, (2). Lapangan hidup keluarga, agar berkembang menjadi keluarga yang sejahtera, (3). Lapangan hidup ekonomi, agar dapat berkembang menjadi sistem kehidupan yang bebas dari penghisapan manusia oleh manusia, (4). Lapangan hidup kemasyarakatan, agar terbina masyarakat yang adil dan makmur di bawah rahmat dan ridha Allah swt. (5). Lapangan hidup politik, agar supaya tercipta sistem demokrasi yang sehat dan dinamis sesuai denga ajaran Islam, (6). Lapangan hidup seni budaya, agar menjadikan hidup manusia penuh keindahan dan kegairahan yang tidak gersang dari nilai moral agama, (7). Lapangan hidup ilmu pengetahuan, agar berkembang menjadi alat untuk mencapai kesejahteraan hidup umat manusia yang dikendalikan oleh iman. Penentuan objek-objek di atas kelihatannya didasarkan pada pandangan beliau mengenai misi Islam yang mencakup tiga dimensi pengembangan hidup manusia, berikut ${ }^{20}$; (1). Dimensi kehidupan duniawi yang mendorong manusia sebagai hamba Allah untuk mengembangkan dirinya dalam ilmu pengetahuan, ketrampilan, dan nilai-nilai yang mendasari kehidupan yaitu nilai-nilai Islam, (2). Dimensi kehidupan ukhrawi yang mendorong manusia untuk mengembangkan dirinya dalam pola hubungan yang serasi dan seimbang dengan Tuhannya. Dimensi inilh yang menurutnya melahirkan berbagai usaha agar kegiatan ubudiahnya senantiasa berada dalam nilai-nilai agamanya, (3). Dimensi hubungan antara kehidupan duniawi dan ukhrawi yang mendorong manusia berusaha untuk menjadikan dirinya sebagai hamba Allah yang utuh dan paripurna dalam ilmu pengetahuan dan ketrampilan, sekaligus sebagai pendukung serta pelaksana pengamal nilai-nilai agamanya

Untuk menjadi modern dan beradab dan agar dapat diterima sejajar dengan Barat, pada dasarnya suatu negara akan menjadi ke-Barat-baratan, sebuah persyaratan yang sebenarnya diragukan, namun banyak negara non-Barat dan negara muslim yang tampaknya menerima pandangan semacam itu. Secara konseptual, pengetahuan asli menggarisbawahi orientasi teoritis dan metodologis dari kerangka Eropasentris dan merekonseptualisasi ketahanan dan kemandirian masyarakat pribumi, dan menitikberatkan pada orientasi agama, filsafat, dan pendidikan mereka sendiri. Maka,

\footnotetext{
${ }^{20}$ Ibid.,h. 31
} 
ia mengisi ruang kosong antara etika dan ilmu pada ilmu dan penelitian yang bersifat Eropasentris; dan juga menciptakan suatu keseimbangan baru dan sudut pandang yang segar, untuk dapat menganalisa pendidikan yang bersifat pedagoginya ${ }^{21}$.

Elmessiri begitu tertarik pada ilmu manusia dan sosial, dan berkontribusi pada proyek Islamisasi Pengetahuan. Dia berpendapat bahwa ilmu manusia dan sosial, dalam kemitraan dengan filsafat modern, berusaha untuk memahami manusia melalui paradigma teori immanentis, naturalistik dan materialistis ${ }^{22}$. Pendekatan ini, menurutnya, dimulai dengan mengurangi kehidupan spiritual, emosional dan budaya ke formula ilmiah, dan berakhir dengan menyangkal bahwa setiap klaim yang dapat diandalkan dapat dibuat tentang fenomena ini sama sekali. dapat dikatakan bahwa filosofis moral Humanisme Islam diperlukan karena paradigma dominan modernitas.

Walaupun penddidikan Islam sebagai suatu disiplin ilmu telah diakui menjadi salah satu bidang studi dan telah menarik minat kalangan pembelajar untuk mengkajinya lebih serius, tetapi sebagai sebuah bidang sstudi yang masih baru tampaknya disiplin ilmu ini belumlah pesat perkembangannya dibandingkan dengan sejumlah bidang studi Islam lainnya. Istilah tarbiyah dalam bahasa Arab, atau "education" dalam bahasa Inggris yang berasal dari bahasa latin "educare" yang diperuntukkan bagi istilah pendidikan menurut Naquib al-Attas tidaklah tepat ${ }^{23}$. Karena terma tarbiyah pada dasarnya berarti mengasuh, menanggung, memberi makan, mengembangkan dan memproduksi hasil-hasil yang sudah matang. Penerapannya dalam bahasa Arab tidak hanya terbatas pada manusia saja. dengan demikian, menurut al-Attas kata tarbiyah sebagai sebuah istilah dan konsep yang bisa diterapkan terhadap berbagai spesies dan tidak terbtas hanya untuk manusia saja, tidak tepat digunakan untuk menunjukkan pendidikan dalam arti Islam, karena

\footnotetext{
${ }^{21}$ Wan Mohd Nor Wan Daud, Educational Philosophy and Practice of Syed Muhammad Naquib al-Attas: An Exposition on the Original Concept of Islamization (Kuala Lumpur: ISTAC, 1998), hal. 1

${ }^{22}$ Helen Elizabeth Mesard, Abdelwahab Elmessiri's Critique of Western Modernity and the Development of an Islamic Humanism, Dissertation presented to the Graduate Faculty of the University of Virginia in Candidacy for the Degree of Doctor of Philosophy Department of Religious Studies (University of Virginia, 2013), hal. 78.

${ }^{23}$ Abdul Ghoni, Pemikiran Pendidikan Naquib al-Attas Dalam Pendidikan Islam Kontemporer, LENTERA: Kajian Keagamaan, Keilmuan dan Teknologi Volume 3, Nomor 1, March 2017 ISSN : 1693-6922 (Print) ISSN: 2540-7767 (Online), hal.56
} 
pendidikan dalam Islam diperuntukan hanya untuk manusia saja. Salah satu penekanan yang diinginkan oleh al-Attas untuk mengganti tarbiyah menjadi ta'dib bagi pendidikan Islam merupakan salah satu upaya merekontruksi kembali arah dan tujuan pendidikan yang dikehendaki oleh al-Attas ${ }^{24}$.

Azyumardi Azra menyatakan bahwa proses pengajaran dalam pendidikan dewasa ini, hanya mengisi aspek kognitif saja, tapi tidak mengisi aspek pembentukan kepribadian dan watak.oleh karena itu, ia menawarkan beberapa arah rekontruksi pendidikan Islam, salah satunya adalah perumusan kembali makna pendidikan dan menyatakan kesetujuannya dengan konsep ta'dib yang diajukan oleh al-Attas ${ }^{25}$. Pembentukan kepribadian seseorang sangat dipengaruhi oleh dimensi ruh yang merupakan anugerah Allah swt, bukan dimensi jasad. Dalam persepektif ini, jasad pada hakikatnya adalah wahana berlakunyad dorongan atau keinginan-keinginan ruhiyah manusia ${ }^{26}$. Dalam persepektif islam, agar tercapainya insan yang kamil melalui pendidikan maka perlu keseimbangan aqal, qalbu, dan nafs. Berdasarkan hal ini, proses ta'lim, tarbiyah, atau ta'dib dalam pembentukan kepribadian muslim harus diawali dari tazkiyatun nafs. Ketika nafs sudah bersih dari pengaruh-pengaruh yang tidak baik maka dengan mudahnya menerima inti dari agama itu sendiri.

\section{c. Kurikulum Pendidikan Islam Menuju Islamisasi Pengetahuan}

Pendidikan merupakan suatu proses penanaman adab ke dalam diri manusia yang merupakan sebuah proses yang sebenarnya tidak dapt diperoleh secara mutlak melalui metode khusus, dalam suatu proses pembelajaran siswa akan mendemontrasikan tingkat pemahamannya terhadap materi secara berbeda-beda, hal ini disebabkan karena ilmu dan hikmah yang merupakan dua komponen utama dalam konsepsi adab benar-benar merupakan suatu anugerah dari Allah swt. Oleh karena itu, muatan pendidikan harus lebih diprioritaskan dibandingkan dengan metodenya, meski lembaga-lembaga pendidikan Muslim modern berada di bawah pengaruh ide-

\footnotetext{
${ }^{24}$ ibid

25 Azyumardi Azra, Paradigma Baru Pendidikan Nasional, Rekontruksi dan Demokratisasi (Jakarta: Kompas, 2002), 121

${ }^{26}$ Al Rasyidin, Falsafah Pendidikan,... hal 88
} 
ide praktek pendidikan Barat yang sekuler cenderung lebih menekankan metode daripada muatan dalam suatu proses pembelajaran. Menurut al-Ghazali ada dua tujuan akhir yang ingin dicapai dalam proses pendidikan, yakni: pertama, mencapai kesempurnaan insani yang bermuara pada pendekatan diri kepada Allah, kedua, kesempurnaan jasmani yang bermuara pada kebahagiaan dunia dan akhirat ${ }^{27}$. Islam harus membuat perencanaan pembuatan kurikulum yang dapat menjadikan peserta didik dapat mengambil andil dalam perkembangan kemajuan dunia yang mengacu kesempurnaan insani dan jasmani.

Dipandang dari sudut keberhasilan pendidikan agama ada tiga indikasipokok, pertama, keberhasilan mentransfer ilmu, kedua pentransferan nilai, ketiga pentransferan ketrampilan. Bagian pertama terkait denganpengetahuan koginitf. Bagian kedua terkait dengan nilai baik dan buruk,peserta didik diarahkan mencintai nilai-nilai kebaikan dan membenci nilainilaikejahatan, bagian ketiga terkait dengan perbuatan nyata ${ }^{28}$.Untuk mengevaluasi apa pendidikan Islam bagi umat Islam berarti, perlu untuk memahami kurikulum di sekolah-sekolah tersebut. Muslim dalam masyarakat bebas yang menempatkan beberapa kendala luar pada perilaku individu, siswa harus benar-benar memahami dan internalisasi Islam prinsip, keyakinan dan praktek, dan belajar bagaimana menerapkannya dalam masyarakat kontemporer.

Segala sesuatu yang penting dalam pendidikan Islam adalah aspek tujuan, dengan mengetahui tujuan maka gerak langkah manusia ke depan akan sesuai dengan konsep yang diinginkan. Tujuan dalam pendidikan Islam sangat dicerminkan oleh sikap atau perilaku masing-masing pelajaran (learning) dengan pribadi-pribadi mereka, dan apa yang berkaitan dengan individu-individu tersebut ada perubahan yang diinginkan pada tingkah laku, aktivitas dan pencapaiannya, dan pada pertumbuhan yang diingini pada pribadi mereka, dan pada persiapan yang dimestikan

\footnotetext{
${ }^{27}$ Abuddin Nata, Pemikiran Para Tokoh Pendidikan Islam, Seri Kajian Filsafat Pendidikan Islam (Jakarta: PT. Raja Grafindo Persada, 2001), 86.

${ }^{28}$ Haidar Putra Daulay, Pemberdayaan Pendidikan Islam di Indonesia, (Jakarta; PT. Rineka Cipta, 2009), hal. 104.
} 
kepada mereka pada kehidupan dunia akhirat ${ }^{29}$.Pandangan ini secara praktis akan menjadi masalah utama pendidikan. Sebab anak bergaul dengan lingkungannya dan mempunyai dorongan yang kuat untuk mengetahui sesuatu. Anak-anak di sekolah atau masyarakat akan menghadapi realita, obyek pengalaman, benda mati, sub human dan human ${ }^{30}$. Demikian juga dengan realita alam semesta ini dan eksistensi manusia yang memiliki jasmani dan rohani. Jadi Anak-anak sebagai peserta didik harus dibimbing, dibina dan ditumbuh kembangkan untuk memahami realitas dunia yang nyata ini dan untuk membimbing pengertian anak-anak dalam memahami suatu realita bukanlah semata-mata kewajiban sekolah atau pendidikan.

Disinilah kurikulum pendidikan islam itu dibentuk secara baik agar dapat megarahkan anak-anak didik menjadi mandiri dalam berbuat kebaikan. Kewajiban sekolah membina kesabaran tentang kebenaran yang berpangkal atas realita, ini berarti realita itu sebagai tahap pertama sebagai stimulus untuk menyelamikebenaran. Peserta didik juga secara sistematis wajib dibina potensi berpikir kritis untuk mengerti kebenaran sesuai dengan tingkatan kemampuannya dalam memahami realita tersebut.Selain dasar pendidikan tersebut, kurikulum juga merupakan hal yang harus disusun dengan tujuan dan target yang ingin dicapai. Kurikulum mempunyai kedudukan yang sentral dalam seluruh proses pendidikan, yang akan mengarahkan segala bentuk aktivitas pendidikan demi tercapainya tujuan-tujuan dalam suatu proses pendidikan. Pendidikan Islam yang dibangun atas dasar pemikiran yang Islami dan bertolak dari pandangan hidup, fungsi serta hakikat manusia, diarahkan kepada tujuan pendidikan yang dilandasi kaidah-kaidah keislaman. Implikasinya akan melahirkan suatu rumusan kurikulum yang khas dan Islami pula. Kekhasan corak kurikulum tersebut adalah penegasannya terhadap pentingnya pemahaman dan aplikasi yang benar mengenai ilmu fard 'ain dan fardu kifayah. Penekanan pada kategorisasi tersebut mungkin karena perhatiannya terhadap kewajiban manusia dalam menuntut ilmu dan mengembangkan adab, hal ini disebabkan karena sifat ilmu yang tidak terbatas pada satu pihak, dan terbatasnya kehidupan individu pada pihak lain.

\footnotetext{
${ }^{29}$ Omar Mohammad At-Toumy Al-Syaibani, Falsafah pendidikan Islam, (Jakarta: Bulan Bintang, 1979), hal. 399

${ }^{30}$ Mohammad Noor, Filsafat Pendidikan,........hal. 30
} 
Struktur ilmu pengetahuan dan kurikulum pendidikan Islam seharusnya menggambarkan manusia dan hakikatnya yang harus diimplementasikan dalam lembaga pendidikan. Struktur, dan kurikulum secara bertahap kemudian diaplikasikan pada tingkat pendidikan secara sistematis. Secara alami, kurikulum tersebut diambil dari hakikat manusia yang bersifat ganda (dual nature), di mana aspek fisikalnya lebih berhubungan dengan pengetahuannya mengenai ilmu-ilmu fisikal dan teknikal atau fardu kifayah. Sedangkan keadaan spiritualnya sebagaimana terkandung dalam istilah ruh, nafs, qalb, dan 'aql lebih tepatnya berhubungan dengan ilmu inti atau fardu 'ain.Pembagian dua jenis ilmu dan penerapannya dalam suatu kurikulum, secara ringkas al-Attas ikhtisarkan sebagai berikut ${ }^{31}$ :

1. Ilmu-ilmu Agama:

a. Al-Qur'an; meliputi pembacaan dan penafsirannya (tafsir dan ta'wil).

b. Al-Sunnah; meliputi kehidupan Nabi, sejarah dan pesan para rasul sebelumya, hadis dan riwayat-riwayat otoritatif.

c. Al-Syari'ah; meliputi undang-undang dan hukum, prinsip-prinsip dan praktikpraktik Islam (Islam, Iman, Ikhsan).

d. Teologi; meliputi Tuhan dan Esensi-Nya, Sifat-sifat dan Nama serta TindakanNya (al Tauhid).

e. Metafisika Islam (al Tasawwuf); psikologi, kosmologi, dan ontologi yang meliputi unsur-unsur yang sah dalam filsafat Islam.

f. Ilmu-ilmu Linguistik; meliputi bahasa Arab, tata bahasa, leksikografi dan kesusasteraan.

2. Ilmu-ilmu Rasional, Intelektual dan Filosofis meliputi:

a. Ilmu Kemanusiaan.

b. Ilmu Alam.

c. Ilmu Terapan.

d. Ilmu Tekhnologi.

${ }^{31}$ Muhammad Naquib Alatas, The Concept of Education in Islam: A Framework for An Philosophy of Education. (Kuala Lumpur: Muslim Youth Movement of Malaysia (ABIM), 1980), hal.87-88. 
Ilmu-ilmu rasional, intelektual dan filosofis pada bagian kedua di atas, menurut al-Attas setiap cabang harus terlebih dahulu diresapi dengan unsur-unsur dan konsep-konsep kunci Islam, setelah unsur-unsur dan konsep-konsep kunci asing dibersihkan dari semua cabangnya. Proses pembuangan dari unsur-unsur dan konsepkonsep kunci asing inilah yang kemudian disebut dengan "Islamisasi", 32 Dasar dari pendidikan Islam, adalah Islam dengan segala ajarannya yang bersumber dari alQur'an, sunnah, ra'yu (hasil pikiran manusia) yang selalu disebut dengan ijtihad. Untuk merealisasikan tujuan pendidikan Islam diperlukan perencanaanpendidikan yang meliputi; (1) kelembagaan, (2) Kurikulum, (3) Manajemen,(4) Pendidik, (5) Peserta didik, (6) alat, sarana, dan fasilitas, (7) kebijakanpemerintah. Hal-hal tersebutlah yang harus didesain berdasarkan islam, terutama diantaranya adalah kurikulum.

Kurikulum merupakan alat untuk mencapai tujuan pendidikan, karena berkaitan dengan penentuan arah pendidikan yang pada akhirnya menentukan kualifikasi lulusan pendidikan. Sebagai alat yang penting untuk mencapai tujuan pendidikan, kurikulum hendaknya dapat mengimbangi perubahan zaman dan kemajuan ilmu pengetahuan serta canggihnya teknologi tanpa mengurangi subtansi dari islam itu sendiri. Kurikulum dikembangkan berdasarkan prinsip bahwa peserta didik memiliki posisi sentral untuk mengembangkan kompetensinya agar menjadi manusia yang bertaqwa, bertauhid, mandiri dan berilmu pengetahuan. Materi pendidikan dan pendidikan Islam tergambar dalam kurikulum yang disusun untuk mewujudkan tujuan pendidikannya. Desain materi pendidikan harus memperhatikan tahap perkembangan peserta didik dan kesesuaiannya dengan lingkungan, perkembangan ilmu pengetahuan yang pada ahir tujuannya adalah dapat menjadikan manusia menjadi khalifah yang amanah di permukaan bumi ini.

Dalam pandangan dunia pendidikan, keberhasilan program pendidikansangat bergantung pada perencanaan program kurikulum, karena kurikulumpada dasarnya berfungsi untuk menyediakan program pendidikan yangrelevan bagi pencapaian sasaran akhir pendidikan. Untuk mencapai hal tersebut kurikulum berfungsi

\footnotetext{
${ }^{32}$ ibid
} 
menyiapkan danmembentuk peserta didik agar dapat menjadi manusia dan sasaran akhirprogram pendidikan. Program kurikulum harus diorientasikan dandisesuaikan dengan kebutuhan masa kini dan masa yang akan datang.Istilah kurikulum digunakan dalam dunia pendidikan dan mengalamiperubahan makna sesuai dengan perkembangan dan dinamika yang ada padadunia pendidikan.

Ditinjau dari historisnya kurikulum dalam pendidikan Islam pada masa klasik, pakar pendidikanIslam menggunakan kata al-maddah untuk pengertian kurikulum, karenapada masa itu kurikulum identik dengan serangkaian mata pelajaran yangharus diberikan pada murid dalam tingkat tertentu ${ }^{33}$.Sejalan dengan perjalanan waktu, pengertian kurikulum mulaiberkembang dan cakupannya lebih luas, yaitu mencakup segala aspek yangmempengaruhi pribadi siswa. Kurikulum dalam pengertian yang modern inimencakup tujuan, isi dan struktur program, proses belajardan mengajar (strategi pencapaian tujuan) serta evaluasi.Bila dikaitkan dengan filsafat dan sistem pendidikan Islam, kurikulumpendidikan Islam mengandung makna sebagai suatu rangkaian programyang mengarahkan kegiatan belajar mengajar yang mencakup seluruh alam semesta serta menggambarkan cita-cita ajaran Islam.Dalam definisi luas kurikulum pendidikan Islam berisikan materi untukpendidikan seumur hidup (long life education) dan yang menjadi materipokok kurikulum pendidikan Islam adalah bahan-bahan, aktivitas, danpengalaman yang mengandung unsur ketauhidan. Secara sistematis kurikulum mencakup komponen tujuan, materi, strategi, evaluasi.

Kurikulum pendidikan islam dalam kacamata filsafat pendidikan islam cenderung bersifat rekonstruktif selektif yang berupaya menampilkan suatu sistem pendidikan Islam terpadu, yang tetap menjaga prinsip keserasian dan keseimbangan individu yang menggambarkan perwujudan fungsi utama manusia sebagai sebagai 'abd Allah dan khalifah al ard. Ilmu pengetahuan dewasa ini telah terkontaminasi oleh pemikiran-pemikiran dari dunia Barat yang sekuler dan bertentangan dengan nilai-nilai ajaran Islam. Oleh karena itu, perlu adanya suatu upaya melalui gerakan "Islamisasi ilmu pengetahuan" dengan mengambil segi-segi positif dari

${ }^{33}$ Nata Abuddin, Sejarah Pendidikan Islam; pada periode Klasik dan Pertengahan, cet. Ke-2, (Jakarta: Raja Grafindo Persada, 2010), hlm. 115 
perkembangan-perkembangan modern seselektif mungkin, meskipun hal itu datangnya dari Barat yang diformulasikan dalam kurikulum pendidikan islam. Kurikulum pendidikan yang diterapkan yakni berusaha mengintegrasikan ilmu pengetahuan yang bersifat fard 'ain dan fard kifayah. Dan pada prinsipnya ini yang tertuang dalam konsep ta'dib sebagai suatu proses penanaman adab yang didalamnya telah mencakup 'ilm dan amal

\section{Kesimpulan}

Pendidikan islam memproyeksikan diri memproduk insan yang kamil, yaitu manusia yang sempurna dalam segala hal. Tujuan proses perkembangan itu secara alamiah adalah kedewasaan atau kematangan. Sebab potensi yang dimiliki oleh manusia secara bertahap berjalan secara alamiah menuju kedewasaan dan kematangan. Dalam pandangan dunia pendidikan, keberhasilan program pendidikan sangat bergantung pada perencanaan program kurikulum, karena kurikulum pada dasarnya berfungsi untuk menyediakan program pendidikan yang relevan bagi pencapaian sasaran akhir pendidikan. Untuk mencapai hal tersebut kurikulum berfungsi menyiapkan dan membentuk peserta didik agar dapat menjadi manusia dan sasaran akhir program pendidikan. Keberhasilan pendidikan agama dilihat dari tiga indikasi pokok; pertama, keberhasilan mentransfer ilmu, kedua pentransferan nilai, ketiga pentransferan ketrampilan. Kurikulum pendidikan islam dalam kacamata filsafat pendidikan islam cenderung bersifat rekonstruktif selektif yang berupaya menampilkan suatu sistem pendidikan Islam terpadu, yang tetap menjaga prinsip keserasian dan keseimbangan individu yang menggambarkan perwujudan fungsi utama manusia sebagai sebagai 'abd Allah dan khalifah al ard. 


\section{Pustaka Acuan}

Al Rasyidin, 2008, Falsafah Pendidikan Islam:membangun Kerangka Ontologi, Epistimologi, dan Aksiologi Praktik Pendidikan Islam, Bandung: Cipta Pustaka Media Perintis.

Al Rasyidin dan Ja'far,2015.Filsafat Ilmu Dalam Tradisi Islam, Medan: Perdana Publishing.

Azra Azyumardi, 2002, Paradigma Baru Pendidikan Nasional, Rekontruksi dan Demokratisasi, Jakarta: Kompas.

Al-Syaibani, Omar Mohammad At-Toumy, 1979, Falsafah pendidikan Islam, Jakarta: Bulan Bintang.

Alatas, Muhammad Naquib, 1980, The Concept of Education in Islam: A Framework for An Philosophy of Education. ,Kuala Lumpur: Muslim Youth Movement of Malaysia (ABIM).

Arifin, Muzayyin,2005 Filsafat Pendidikan Islam, Jakarta; PT Bumi Aksara.

Baharuddin, Dkk. 2011, Dikotomi Pendidikan Islam: Historisitas dan Implikasi Pada Masyarakat Islam, (Bandung: Remaja Rosdakarya.

Daulay Haidar Putra, 2009, Pemberdayaan Pendidikan Islam di Indonesia, Jakarta; Rineka Cipta.

Ghoni, Abdul, 2017, Pemikiran Pendidikan Naquib al-Attas Dalam Pendidikan Islam Kontemporer, LENTERA: Kajian Keagamaan, Keilmuan dan Teknologi Volume 3, Nomor 1, March 2017 ISSN : 1693-6922 (Print) ISSN: 2540-7767 (Online)

Daud, Wan Mohd Nor Wan, 1998.Educational Philosophy and Practice of Syed Muhammad Naquib al-Attas: An Exposition on the Original Concept of Islamization, Kuala Lumpur: ISTAC.

Mesard, Helen Elizabeth, 2013,Abdelwahab Elmessiri' $s$ Critique of Western Modernity and the Development of an Islamic Humanism, Dissertation presented to the Graduate Faculty of the University of Virginia in 
Candidacy for the Degree of Doctor of Philosophy Department of Religious Studies, University of Virginia,

Nata, Abuddin, 2001, Pemikiran Para Tokoh Pendidikan Islam, Seri Kajian Filsafat Pendidikan Islam ,Jakarta: Raja Grafindo Persada.

Nata Abuddin, Sejarah Pendidikan Islam; pada periode Klasik dan Pertengahan, cet. Ke-2, (Jakarta: Raja Grafindo Persada, 2010

Syam, Muhammad Noor, 1986Filsafat Kependidikan dan Dasar Filsafat Kependidikan Pancasila, Surabaya: Usaha Nasional.

Sanjaya, Wina, 2008. Kurikulum dan Pembelajaran: Teori dan Praktik Pengembangan KTSP, Jakarta; Kencana Prenada Media Group.

Tymieniecka, Anna-Teresa (ed), 2013.Reason, Spirit and the Sacral in the New Enlightenment Islamic Metaphysics Revived and Recent Phenomenology of Life,(Hampshire, USA : 2011.VOLUME 5),

Uhbiyati, Nur, 1997 Ilmu Pendidikan Islam,Bandung; CV. Pustaka Setia.

Walidin, Warul, 2003. Konstelasi Pemikiran Ibnu Khaldun, Lhokseumawe: Nadiya Foundation 